\title{
ИСТОРИКО-КУЛЬТУРНОЕ ЗОНИРОВАНИЕ КАК СПОСОБ РАЗВИТИЯ ГОРОДСКОГО ПРОСТРАНСТВА
}

Аннотация. В статье рассматриваются проблемы развития городского пространства с позиции культурно-ландшафтного подхода. Исторический город характеризуется как тип культурного ландшафта, который может включать в свой состав другие разновидности культурных ландшафтов. Автор акцентирует внимание на особенностях сохранения объектов наследия городов в зависимости от их размеров и административных функций. В качестве перспективного способа структурирования пространства средних и крупных городов предлагается историко-культурное зонирование. Данный прием при правильной реализации позволяет сочетать деятельность по сохранению объектов наследия с решением проблем развития городской инфраструктуры.

Ключевые слова: культурное наследие, культурный ландмафт, культурно-ландшафтный подход, сохранение наследия, исторический город, городское пространство, брендинг.

Изучение проблематики развития городского пространства имеет междисциплинарный, интегративный характер. В зависимости от специфики области научного знания формулируются и уточняются приоритетные направления исследования города как комплексного явления, однако адекватный ответ на вопрос о стратегии разнопланового развития современного городского пространства возможно сформулировать исключительно на основе взаимодействия специалистов разного профиля и достижения компромиссных решений.

На сегодняшний день городское пространство анализируется в рамках урбанистических исследований, в логике формирования и трансформации агломераций, а также создания и продвижения региональных и локальных брендов. В последние годы развитие городского пространства связывают с вопросами формирования территориальной идентичности $[1$, с. $156-$ 160]. Залогом успешного развития городов в современных условиях признается разноплановость государственной культурной политики, нацеленной на «позиционирование их как центров инноваций с высокой степенью гетерогенности, изменчивости и вариативности» [2, c. 267].

В конце XX в. в отечественной науке и практической деятельности музейных учреждений активное развитие получил культурноландшафтный подход к сохранению объектов наследия. Согласно этому подходу наследие воспринимается как исторический феномен, сформировавшийся во взаимодействии челове- ческого общества и природной среды, развивающийся под влиянием социально-культурного окружения и экономических факторов, трансформирующийся с течением времени и приобретающий новые компоненты. В этом контексте наследие характеризуется фундаментальной значимостью, целостностью, репрезентативностью и достоверностью [3, с. 7-8]. В рамках данного подхода выделяют несколько типов культурных ландшафтов: исторический город, историческая сельская местность, исторический парк. В последнее время наблюдается тенденция выделения дополнительных типов ландшафтов. Однако среди разновидностей культурного ландшафта исторический город выступает как комплексное явление, зачастую включающее в себя другие типы.

Специфика сохранения культурного наследия зависит от размеров и современных функций городов. Полномасштабная консервация и последующая реставрация памятников истории и культуры возможны только при условии относительной компактности городского пространства. Эта деятельность, как правило, затрудняется выполнением городом государственных функций, связанных с функционированием разветвленных административных структур. В этом смысле малые города, которые могут быть отнесены к категории исторических, имеют потенциал превращения в своеобразные комплексные музеи под открытым небом, города-музеи. Ярким примером данного категории городов является Суздаль Владимирской области, ставший центром сохранения наследия и 
развития туризма еще в советский период. На рубеже XX-XXI вв. применение инструментов описываемого подхода стало одним из возможных путей выработки стратегии развития малых городов при выходе из социальноэкономического кризиса $[4$, с. $18-27]$.

Данный подход не может быть реализован для городов средних и крупных размеров. Поскольку специфика развития этих городов привела к формированию различных по назначению и функционированию компонентов, комплексная консервация объектов наследия стала фактически невозможна. Города средних размеров и мегаполисы являются динамично, а зачастую хаотично развивающимися феноменами. Современные реалии порождает противоречие между стремлением и реальными действиями к сохранению объектов наследия, с одной стороны, и необходимостью развития городской инфраструктуры, с другой. Одним из возможных вариантов разрешения этого противоречия является сохранение исторического ядра города [5, с. 310-316]. Примером, этой формы развития городского пространства является г. Ярославль, исторический центр которого в 2005 г. был внесен в список Всемирного наследия ЮНЕСКО.

В качестве инновационного способа развития современного городского пространства может быть предложено историко-культурное зонирование. Этот прием базируется на теоретической основе культурно-ландшафтного подхода. Наиболее перспективными элементами городского пространства для осуществления историко-культурного зонирования являются промышленные районы, исторические кварталы, улицы и бульвары, площади, городские парки и скверы, набережные. Как правило, они становятся точками сосредоточения культурной жизни населения городов, поскольку задействуются для проведения мероприятий разной направленности, а также используются в качестве локаций для неформального времяпрепровождения [6, с. 224-225].

На сегодняшний день многие подлинные объекты наследия приходят в упадок и разрушаются, уступая свое место в городском пространстве торговым и офисным помещениям, многоквартирным жилым постройкам, объектам индустрии развлечений. Важно отметить, что историко-культурное зонирование предполагает сочетание новых элементов городского ландшафта с подлинными объектами наследия, а не заполнение облика города арт-объектами, не связанными с историей городов и имеющими сомнительную культурно-эстетическую цен- ность. Предлагаемый способ позволяет наглядно продемонстрировать различные исторические периоды, отразившиеся в развитии конкретной части городского пространства. Оптимальным приемом реализации историкокультурного зонирования является мягкая музеефикация, позволяющая использовать функционирующие объекты или объекты, которым возвращено первоначальное назначение, при раскрытии их культурной значимости.

По мнению Н. А. Лещенко, объекты наследия исторического города «должны быть активно вовлечены в современную городскую жизнь, иметь востребованные функции и быть социально ценными» $[7$, с. 7]. Автор на примере памятников архитектуры рассматривает процесс ревалоризации исторической среды, предлагая «восстановление нарушенных, воссоздание разрушенных и обозначение утраченных» объектов c соблюдением ландшафтных характеристик городского пространства [7, с. 9]. Анализируя перспективы развития городских парков как составляющей городской среды, М. Н. Силкина предлагает реконструировать фрагменты городских садов (беседки, аллеи со скульптурами, танцевальные площадки, сцены под открытым небом), презентующих различные десятилетия советского периода [8, с. 511-512].

Примерами удачного использования историко-культурного зонирования является воссоздание пространств исторических частей города в сочетании с современной инфраструктурой: пешеходная улица Баумана в г. Казань и 130 квартал (Иркутская слобода) в г. Иркутск. Кроме того, распространенным явлением в разных городах становится реконструкция фрагментов исторических мостовых. Динамичное развитие на сегодняшний день получили приемы историко-культурного зонирования при развитии туристских маршрутов Тюмени и других исторических городов Тюменской области. В Кемеровской области - Кузбассе успешным примером восстановления объекта культурного наследия является воссоздание первоначального облика Дворца культуры в г. Салаир.

Таким образом, в условиях поиска оптимальных путей развития городов, ориентируясь на формирования его уникального образа и туристской привлекательности, необходимо не только решать инфраструктурные и логистические проблемы, но и использовать потенциал наследия для гармоничного развития общества. Сегодня, когда исторический облик городов средних размеров и мегаполисов в значительной степени трансформировался, а подлинные 
объекты утрачивают свое первоначальное назначение или разрушаются, применение приемов историко-культурного зонирования может являться компромиссным способом совершенствования городского пространства. Исторически репрезентативные компоненты городов (промышленные районы, исторические кварталы, улицы и площади, городские парки и скверы, набережные) должны не только описываться в научных трудах и презентоваться в музейных экспозициях, но и становиться частью современной социально-культурной среды.

\section{Список литературы}

1. Агеев И. А. Брендинг города и региона как средство формирования территориальной идентичности: исторический опыт сибирских городов // Вестник науки Сибири. 2015. № 2 (17). C. $155-163$.

2. Гун Г. Е. Концептуальные основы культурной политики для городов // Теория и практика общественного развития. 2014. № 6. C. 265-267.

3. Веденин Ю. А. Базовые принципы культурно-ландшафтного подхода к изучению и сохранению наследия // Наследие и современность. 2020. Т. 3. № 2. С. 7-20.

4. Штеле О.Е. Культурное наследие как основа социально-экономического развития малого исторического города (на примере города Мышкина Ярославской области) // Вестник Московского городского педагогического уни- верситета. Серия: Естественные науки. 2020. № 2 (38). C. 16-27.

5. Колосова И. И., Типтева Д. Н. Исторический центр города в структуре современных городов // Инвестиции, градостроительство, недвижимость как драйверы социальноэкономического развития территории и повышения качества жизни населения: материалы XI Международной конференции. Томск, 2021. C. $310-316$.

6. Насонов А. А., Иванов Е. В. Адаптация культурно-ландшафтного подхода к сохранению наследия и туристскому использованию наследия исторических городов Южной Сибири // Ярослав Мудрый. Проблемы изучения, сохранения и интерпретации историко-культурного наследия: сборник материалов Международной научно-практической конференции. Ярославль, 2018. C. 221-226.

7. Лещенко Н. А. Ревалоризация как реставрационная трансформация для создания качественной городской среды исторического малого города // Вестник Брестского государственного технического университета. 2018. № 1 (109). C. 7-10.

8. Силкина М.Н. Исторические парки и перспективы применения культурноландшафтного подхода к современной городской среде // Кузбасс: образование, наука, инновации: материалы Инновационного конвента. Новокузнецк, 2016. С. 508-512.

Научный руководитель - И. А. Жерносенко, доктор философских наук, доцент Алтайский государственный институт культуры (Россия, Барнаул) irina.jernosenko@gmail.com

\section{ВЕЛИКАЯ ОТЕЧЕСТВЕННАЯ ВОЙНА В ПРОИЗВЕДЕНИЯХ КОМПОЗИТОРОВ АЛТАЙСКОГО КРАЯ}

Аннотация. В данной статье рассматриваются произведения алтайских композиторов А. С. Анохина и В. И. Шардакова, посвященные Великой Отечественной войне. Через сохранение и трансляцию нематериального культурного наследия важно популяризировать вокально-хоровое творчество композиторов Алтайского края. Тема Великой Отечественной войны всегда наполнена эмоциями тоски, печали, победной радости и горечи потерь. Сохранение памяти о событиях военных лет не просто важно для будущих поколений. Без этой памяти невозможно построить общество будущего, здоровое духовно и ответственное за свои деяния. Целью данного исследование является 